\title{
Front Matter: Volume 10941
}

, "Front Matter: Volume 10941," Proc. SPIE 10941, Emerging Liquid Crystal Technologies XIV, 1094101 (23 May 2019); doi: 10.1117/12.2531312

SPIE. Event: SPIE OPTO, 2019, San Francisco, California, United States 


\title{
PROCEEDINGS OF SPIE
}

\section{Emerging Liquid Crystal Technologies XIV}

\author{
Liang-Chy Chien \\ Dirk J. Broer \\ Igor Muševič \\ Byoungho Lee \\ Editors
}

3-5 February 2019

San Francisco, California, United States

Sponsored and Published by

SPIE 
The papers in this volume were part of the technical conference cited on the cover and title page. Papers were selected and subject to review by the editors and conference program committee. Some conference presentations may not be available for publication. Additional papers and presentation recordings may be available online in the SPIE Digital Library at SPIEDigitalLibrary.org.

The papers reflect the work and thoughts of the authors and are published herein as submitted. The publisher is not responsible for the validity of the information or for any outcomes resulting from reliance thereon.

Please use the following format to cite material from these proceedings:

Author(s), "Title of Paper," in Emerging Liquid Crystal Technologies XIV, edited by Liang-Chy Chien, Dirk J. Broer, Igor Muševič, Byoungho Lee, Proceedings of SPIE Vol. 10941 (SPIE, Bellingham, WA, 2019) Seven-digit Article CID Number.

ISSN: 0277-786X

ISSN: 1996-756X (electronic)

ISBN: 9781510625242

ISBN: 9781510625259 (electronic)

Published by

SPIE

P.O. Box 10, Bellingham, Washington 98227-0010 USA

Telephone +1 3606763290 (Pacific Time) · Fax +1 3606471445

SPIE.org

Copyright (C) 2019, Society of Photo-Optical Instrumentation Engineers.

Copying of material in this book for internal or personal use, or for the internal or personal use of specific clients, beyond the fair use provisions granted by the U.S. Copyright Law is authorized by SPIE subject to payment of copying fees. The Transactional Reporting Service base fee for this volume is $\$ 18.00$ per article (or portion thereof), which should be paid directly to the Copyright Clearance Center (CCC), 222 Rosewood Drive, Danvers, MA 01923. Payment may also be made electronically through CCC Online at copyright.com. Other copying for republication, resale, advertising or promotion, or any form of systematic or multiple reproduction of any material in this book is prohibited except with permission in writing from the publisher. The CCC fee code is 0277$786 \mathrm{X} / 19 / \$ 18.00$.

Printed in the United States of America by Curran Associates, Inc., under license from SPIE.

Publication of record for individual papers is online in the SPIE Digital Library.

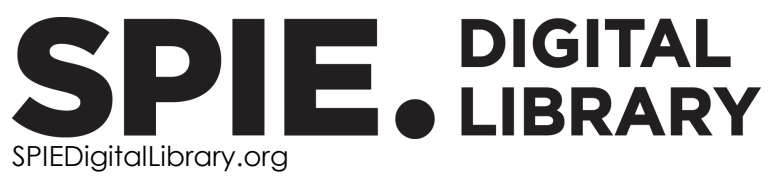

Paper Numbering: Proceedings of SPIE follow an e-First publication model. A unique citation identifier (CID) number is assigned to each article at the time of publication. Utilization of CIDs allows articles to be fully citable as soon as they are published online, and connects the same identifier to all online and print versions of the publication. SPIE uses a seven-digit CID article numbering system structured as follows:

- The first five digits correspond to the SPIE volume number.

- The last two digits indicate publication order within the volume using a Base 36 numbering system employing both numerals and letters. These two-number sets start with $00,01,02,03,04$, 05, 06, 07, 08, 09, 0A, OB ... 0Z, followed by 10-1Z, 20-2Z, etc. The CID Number appears on each page of the manuscript. 


\section{Contents}

$\begin{array}{ll}\vee & \text { Authors } \\ \text { vii } & \text { Conference Committee }\end{array}$

NEW MATERIALS AND EFFECTS

1094106 A fluid liquid crystal with ferroelectric-like order (Invited Paper) [10941-5]

109408 Theoretical study on optical properties of liquid crystalline Skyrmion lattice (Invited Paper) [10941-22]

1094109 Electro-optics of liquid crystal cells utilizing weakly conducting polymers as electrodes and alignment layers [10941-8]

\section{SENSORS AND ACTUATORS}

10941 OA Remote and autonomous temperature measurement based on 3D liquid-crystal microlasers [10941-9]

10941 OC Novel devices with photosensitive elements (Invited Paper) [10941-11]

\section{SPATIAL LIGHT MODULATORS AND FILTERS}

10941 OD Terahertz wave manipulation and detection based on liquid crystals (Invited Paper) [10941-12]

10941 OE Design, implementation, and study of the high-resolution high-efficiency liquid crystal on silicon spatial light modulator for the telecommunication application in the short-wave infrared spectral band [10941-13]

10941 OF Polarization-independent beam-steering system based on liquid-crystal spatial light modulators [10941-14]

10941 OG Hyper-Rayleigh scattering measurements of magnetite nanoparticles: determination of the first order hyperpolarizability anisotropy [10941-15]

POLYMER AND LIQUID CRYSTAL COMPOSITES

10941 ol Surface structures of hybrid aligned liquid crystal network coatings containing reverse tilt domain (Invited Paper) [10941-17] 
10941 OJ Formation of polymer structure by thermally induced phase separation in a dye-doped liquid crystal cell [10941-18]

\section{CHIRAL PHASES AND DEVICE APPLICATIONS}

10941 OM Angular dependent spontaneous emission in cholesteric liquid-crystal films (Invited Paper) [10941-21]

\section{LENSES AND 3D DISPLAYS}

1094100 Dynamically manipulated accommodation-invariant displays (Invited Paper) [10941-27]

\section{GRATINGS AND DIFFRACTIVE WAVE PLATES}

10941 OR Design methods for diffractive waveplate geometric phase elements (Invited Paper) [10941-24]

10941 OT Spontaneous formation of polarization diffraction gratings in surface-stabilized cells filled with liquid crystal in the modulated nematic phase [10941-26]

\section{POSTER SESSION}

10941 OU A new type of liquid-crystal cylindrical microlens arrays with nonuniform microcoil electrodes [10941-29]

$109410 V \quad$ Reflectance tuned at infrared wavelengths based on aluminum metasurfaces [10941-30] 


\title{
Authors
}

Numbers in the index correspond to the last two digits of the seven-digit citation identifier (CID) article numbering system used in Proceedings of SPIE. The first five digits reflect the volume number. Base 36 numbering is employed for the last two digits and indicates the order of articles within the volume. Numbers start with $00,01,02,03,04,05,06,07,08,09,0 A, 0 B \ldots . .0 Z$, followed by 10-12, 20-2Z, etc.

\author{
Ali, Muhammad, OT \\ Babakhanova, Greta, 0 l \\ Broer, Dirk J., Ol \\ Chen, Mingce, OU, oV \\ Chen, Po-Ju, OE \\ Cho, Jaebum, 00 \\ Choi, Tae-Hoon, OJ \\ Choi, Yeongyu, OJ \\ De Boni, L., OG \\ Engel, Philip, OE \\ Figueiredo Neto, A. M., OG \\ Fonseca, R. D., OG \\ Fukuda, Jun-ichi, 08 \\ Garbovskiy, Y., 09 \\ Gleeson, Helen F., OC \\ Glushchenko, A., 09 \\ Gonçalves, E. S., OG \\ Gorecka, Ewa, OT \\ Guo, Hongru, OF \\ Han, Xinjie, OU \\ Haseba, Yasuhiro, 06 \\ $\mathrm{He}$, Xiaoxian, OF \\ Higuchi, Hiroki, 06 \\ Humar, Matjaž, OA \\ Imrie, Corrie, OT \\ Jo, Youngjin, 00 \\ Jull, Ethan I. L., OC \\ Kikuchi, Hirołsugu, 06 \\ Lavrentovich, Oleg D., Ol \\ Lazarev, Grigory, OE \\ Lee, Byoungho, 00 \\ Lee, Seungjae, 00 \\ $\mathrm{Li}$, Zheng, OU \\ Liu, Mengna, OV \\ LU, Y. Q., OD \\ Majewski, Pawel W., OT \\ Mazur, Adam, OE \\ Muševič, lgor, OA \\ Nakajima, M., OD \\ Nishikawa, Hiroya, 06 \\ Oh, Seung-Won, OJ \\ Okumura, Yasushi, 06 \\ Pirnat, Gregor, OA \\ Pociecha, Damian, OT \\ Risse, Anna M., OM \\ Sago, Koki, 06 \\ Schenning, Albert P. H. J., Ol \\ Schmidtke, Jürgen, $O M$ \\ Shao, Qi, OU
}

\author{
Shiroshita, Kazuya, 06 \\ Tan, Qinggui, OF \\ Urbach, H. Paul, OE \\ Vaupotič, Nataša, OT \\ Walsh, Gary F., OR \\ Wang, Haiwei, OU, OV \\ Wang, L., OD \\ Wang, Xiangru, OF \\ Wei, Dong, OU, OV \\ Wu, Liang, OF \\ Xie, Changsheng, OU, OV \\ Xin, Zhaowei, OU, OV \\ Xiong, Caidong, OF \\ Yamamoto, Shin-ichi, 06 \\ Yoo, Dongheon, 00 \\ Yoon, Tae-Hoon, OJ \\ Yu, Byeong-Hun, OJ \\ Zhang, Xinyu, OU, OV \\ Žumer, Slobodan, 08
}


Proc. of SPIE Vol. 10941 1094101-6

Downloaded From: https://www.spiedigitallibrary.org/conference-proceedings-of-spie on 26 Apr 2023 Terms of Use: https://www.spiedigitallibrary.org/terms-of-use 


\section{Conference Committee}

Symposium Chairs

Connie J. Chang-Hasnain, University of California, Berkeley (United States)

Graham T. Reed, Optoelectronics Research Centre, University of Southampton (United Kingdom)

Symposium Co-chairs

Sailing He, KTH Royal Institute of Technology (Sweden) and Zhejiang University (China)

Yasuhiro Koike, Keio University (Japan)

Program Track Chair

Liang-Chy Chien, Kent State University (United States)

Conference Chair

Liang-Chy Chien, Kent State University (United States)

Conference Co-chairs

Dirk J. Broer, Technische Universiteit Eindhoven (Netherlands)

Igor Muševič, Jožef Stefan Institute (Slovenia)

Byoungho Lee, Seoul National University (Korea, Republic of)

Conference Program Committee

Etienne Brasselet, Université de Bordeaux (France)

Vladimir G. Chigrinov, Hong Kong University of Science and

Technology (Hong Kong, China)

Michael Escuti, North Carolina State University (United States)

Antonio M. Figueiredo Neto, Universidade de São Paulo (Brazil)

Andy Ying-Guey Fuh, National Cheng Kung University (Taiwan)

Jun-ichi Fukuda, Kyushu University (Japan)

Tigran Galstian, Centre d'Optique, Photonique et Laser (Canada)

Linda S. Hirst, University of California, Merced (United States)

Hirotsugu Kikuchi, Kyushu University (Japan)

Heinz S. Kitzerow, Universität Paderborn (Germany)

Jan P. F. Lagerwall, Université du Luxembourg (Luxembourg)

Yi-Hsin Lin, National Chiao Tung University (Taiwan)

Akihiro Mochizuki, i-CORE Technology, LLC (United States)

Kristiaan Neyts, Universiteit Gent (Belgium) 
Toshiaki Nose, Akita Prefectural University (Japan)

Masanori Ozaki, Osaka University (Japan)

Miha Ravnik, University of Ljubljana (Slovenia)

Ivan I. Smalyukh, University of Colorado Boulder (United States)

Nelson V. Tabiryan, BEAM Engineering for Advanced Measurements Company (United States)

Timothy J. White, University of Colorado Boulder (United States)

Michael Wittek, Merck KGaA (Germany)

Shin-Tson Wu, CREOL, The College of Optics and Photonics, University of Central Florida (United States)

Jun Yamamoto, Kyoto University (Japan)

Tae-Hoon Yoon, Pusan National University (Korea, Republic of)

Session Chairs

1 Colloids and Nanoparticles Dispersions

Jun-ichi Fukuda, Kyushu University (Japan)

2 New Materials and Effects

Antônio M. Figueiredo Neto, Universidade de São Paulo (Brazil)

3 Sensors and Actuators

Oleg D. Lavrentovich, Kent State University (United States)

$4 \quad$ Spatial Light Modulators and Filters

Igor Muševic, Jožef Stefan Institute (Slovenia)

5 Polymer and Liquid Crystal Composites

Carlos Sánchez-Somolinos, Instituto de Ciencia de Materiales de Aragón (Spain)

6 Chiral Phases and Device Applications

Jun Yamamoto, Kyoto University (Japan)

$7 \quad$ Lenses and 3D Displays

Nelson V. Tabirian, BEAM Engineering For Advanced Measurements Company (United States)

8 Gratings and Diffractive Wave Plates

Tigran Galstian, Centre d'Optique, photonique et laser (Canada) 